Macedonian Academy of Sciences and Arts, Skopje

ilijacasule@gmail.com

\title{
THE ETYMOLOGY AND CORRELATION OF THE ANCIENT MACEDONIAN GLOSS LAKEDAMA AND PHRYGIAN LAKEDOKEY
}

\begin{abstract}
This is an etymological analysis of the Ancient Macedonian gloss $\lambda \alpha \kappa \varepsilon \delta \alpha ́ \mu \alpha$ lakedama 'salt water drunk by Macedonian peasants', found in Hesychius and the Old Phrygian form lakedokey from the Areyastis inscription. We propose that in both cases we have compound words, where the shared first stem lake- should be derived from PIE *lak(u)- 'body of water, lake, sea'. We contend that the second components of both words, while of different origin, convey a basic meaning of 'special, good, preferred; prepared'. While limited, this etymology points to a closer correlation between Phrygian (Brygian) and Ancient Macedonian.
\end{abstract}

\section{Introduction}

Very little is preserved of Ancient Macedonian (a Paleobalkanic language, term put forward by Vladimir Neroznak (1978), (Katičić uses the term Ancient Balkan language (1976 and in the literature therein). There are approximately some 200 glosses and no inscriptions or running text. A large number of these glosses reveal a language that should be classified as separate from Ancient Greek, even though the issue whether Ancient Macedonian is a Greek dialect or a different language has provoked quite divergent analyses, some even diametrically opposed to each other (see the discussion in Katičić (1976).

A good number of these glosses have uncertain or problematic etymologies and some seem unique within Indo-European. A few may not be Indo-European at all, as they do not resemble anything in Proto-Indo-European as currently reconstructed. Some exhibit phonemic changes clearly not characteristic of any known Ancient or Modern Greek dialect. It is also evident (and expected) that Ancient Macedonian has borrowed from Ancient Greek (and Ancient Greek from Ancient Macedonian) due to intense and prolonged language contact. 
The lexicographer Hesychius of Alexandria $\left(5^{\text {th }}\right.$ century CE) has been the main source for these glosses and lexemes ${ }^{1}$ from various "extinct" Paleobalkanic languages, like Thracian, Illyrian, Paeonian (only 1 gloss), and especially Phrygian. ${ }^{2}$

Phrygian (< Brygian) was originally spoken in Central and Northern Macedonia (see Georgiev 1981: 212, or Petrova 1996). It appears only in inscriptions in Asia Minor, after the migration of a large populace of Bryges around the $13^{\text {th }}$ century BCE from central Macedonia to Anatolia (Petrova 1996).

As stated by Herodotus of Halicarnassus, the name Phruges is the Greek version of the original ethnonym Bruges, which this population adopted after their migration to Anatolia (Anadolia).

We provide an etymological analysis of an Ancient Macedonian gloss and an Old Phrygian form extrapolated from an inscription (the so-called Areyastis inscription, see Lubotsky 1988). Both of these words do not have heretofore satisfactory etymologies, and they may provide still limited evidence of a correlation between Phrygian and Ancient Macedonian.

\section{Ancient Macedonian lakedama}

Lakedama is found as a gloss in Hesychius - 'lakedama: bitter water made in the sea [poured out in salt flats] which the Macedonian peasants drink', usually simplified in references as 'some salt water drunk by Macedonian peasants'.

Our analysis of the etymology of this clearly compound noun (quite unique in meaning) proposes a segmentation $\{l a k-e-d a m-a\}$.

\subsection{First stem lak-e-}

We trace the origin of the first root (stem) lak- from PIE *lak(u)'body of water, lake, sea' > Latin lacus 'pond, pool, lake', Old Church Slavonic loky 'pool, puddle, cistern' (Serbian and Croatian lokva 'pond'), Ancient Greek lakkos 'pit, tank, pond', Old Irish loch 'lake, pond', German Lake 'salt water', Gothic lagus 'lake, sea, [importantly] water' (Pokorny 1959: 653). The Germanic semantic development ['salt water' and 'water' (general term)] is perhaps most indicative of the semantics of the Ancient Macedonian gloss.

${ }^{1}$ There are also Phrygian and Paleobalkanic glosses in works by lexicographers like Neoptolemus and Clement of Alexandria.

${ }^{2}$ Phrygian has been preserved, apart from the glosses in Hesychius, in some 240 inscriptions which date from the VIII-III century BCE (Old Phrygian, to which the Areyastis inscription belongs) and approximately 100 inscriptions from the IV century CE. Some scientists believe it became extinct in the VII century CE (Mallory-Adams 1997: 418). 
There is also Proto-Slavic *lokati 'drink a lot, gulp' (that we correlate here, but does not seem to have a decisve etymology ${ }^{3}$ ) from which there is Macedonian loka 'drink a lot, gulp down' (an expressive form, sometimes referring specifically to '(excessive) drinking of alcohol', also Serbian and Croatian lokati, Russian lokát', Polish tokać 'same', and further Croatian podlokavati 'erode (of water)' and Macedonian podlokuva 'same'.

-e- in lak-e- is possibly a case form [genitive? < Proto-Indo-European $\left.*_{-} e(s)\right]$ or simply a joining vowel in a compound form.

\subsection{Second stem -dam-a}

We propose a derivation of -dam- $a$ from PIE *dhabh- 'proper, suitable; to fit/put together'> Old Norse dafna 'competent, good', Serbian, Croatian, Macedonian dobar, Russian dobryi 'good', found throughout Slavic, and Lithuanian dabinti 'to decorate' and esp. dabá 'quality' (Mallory-Adams 1997:139) (Pokorny 1959: 233-234).

The Lithuanian noun corresponds exactly in form (with an ending $-a$ ) with the second stem of the Ancient Macedonian gloss.

The phonemic change $b h>m$ needs to be explained.

This change has been proposed in the analysis of another Ancient Macedonian gloss: dramis 'a type of Macedonian bread' (yet also found in other areas). Fick, Pisani, Walde-Pokorny (1927-1932: I 876; 856) apud Barić (1948: 176) derive dramis ${ }^{4}$ from IE *dhrebh- 'to crush, to grind', as in Greek trophalis 'fresh cheese', thrombeion 'croquette', Old Norse drafl 'fresh cheese' with, as they state, with the characteristic_Ancient Macedonian change $b h>m$.

This etymology most likely reveals a meaning of lak-e- '(salty?) water from pond (sea?)', + -dam-a 'suitable, preferred, good'. The contemporary Macedonian verb loka, Serbian and Croatian lokati 'drink a lot, gulp; sip' (with an alternation $a: o$, seems to be closest semantically, in the sense of 'water you drink a lot of (in hot weather, at harvest time for the peasants?). ${ }^{5}$ We also have Serbian and Croatian lokva 'puddle, pond'.

\footnotetext{
${ }^{3}$ Hrvatski portal (Croatian Language Portal) [http://hjp.znanje.hr/index.php?show =search_by_id\&id=e15iXBY\%3D] puts forward the following etymological correlation.

$\diamond$ Proto-Slavic *lokati (Russian lokát', Polish tokać), lit. lakti: laptati ? $\simeq$ Greek láptein: 'to lick', which is not convincing and very tentative.

${ }^{4}$ A continuant of dramis is also found in Burushaski, which is closely related to Phrygian as we have shown in Čašule 2004, 2014; extensively and specifically on this correlation, also Čašule 2016, 2017, 2018) as diram phiti 'a type of ritual bread, where diram is 'a type of flour' [Lorimer 1938: 131, Berger 1998: 120, for the etymological analysis of the Burushaski noun, see Čašule (2017: 120)].

${ }^{5}$ Macedonian peasants today, esp. in the hottest region of the Republic of Macedonia (in and around the township of Demir Kapija and elsewhere) still drink in summer a type of salt water (with garlic) when harvesting in extreme heat, which is extralinguistic evidence that should not be ignored.
} 


\section{Old Phrygian lakedokey}

We find the Phrygian form (verb?) in the so-called Areyastis inscription for which Lubotsky (1988: 21) considers, but rejects summarily a segmentation lake-dokey because he cannot find an etymological explanation of lake- and thus leaves the form and the semantics unexplained. ${ }^{6}$

The second stem in the Old Phrygian lakedokey, that is, dokey can be derived from IE * $d h \bar{O} k$ - to do, to make, to set, to put' (Pokorny 1959 235): the attested Phrygian form is ad-daket 'afficit' (Phrygian forms importantly also in *dok- and *dik-) and further in Indo-European Latin facere 'to do', Old Latin fefaked 'to do', Hittite dakkezi 'makes', Greek theké 'receptacle', (given here also Tocharian A taka 'I became'). In Burushaski we have the verbal periphrastic expression doók man- 'to put or set down' or doók étas 'to build; place, lift a stone' (see the full analysis in Čašule 2017: 121-122).

Thus, the Phrygian (Brygian) form lakedokey, whether a verb meaning 'to offer (salt?) water' or of nominal or adjectival origin with the meaning '(salt) water' obtains a semantics of 'prepared $(<$ made $)$ '.

\section{Conclusion.}

The correlation (both phonemic and semantic) of Old Phrygian $(<\text { Brygian })^{7}$ lakedokey with Ancient Macedonian lakedama which share the first stem lake- from PIE *lak(u)- 'pond, lake, sea) is very close.

Both second components of the compound words have the same semantics of 'special, (home?) made water, preferred, +/- good' which results in a robust etymological solution.

Our etymological analysis provides a solid etymology for an Ancient Macedonian gloss heretofore labeled as "unknown".

It also puts forward (albeit limited) evidence for the theory that Ancient Macedonian could be ultimately a language of Brygian origin in close contact with Ancient Greek. ${ }^{8}$

${ }^{6}$ Italo Cucaro (p.c. on Academia.edu) proposes tentatively a possible semantics for the Old Phrygian word of 'salt-water libation; an offering of salt-water libation'.

${ }^{7}$ Future studies should refer to the Phrygian language also with the self-denomination of these people, that is, Bryges.

${ }^{8}$ Hamp (1990) (2013) and Diakonoff-Neroznak (1985), also Neroznak (1978) even Orel (1997) also to a large degree Haas (1966) consider Greek and Phrygian quite distant. Hamp classifies it is a North-Western Indo-European language, a par with Germanic, Baltic and Slavic (Balto-Slavic ?), Thracian, Pre-Hellenic, Tocharian, Albanian and Italic and Celtic (see Hamp's genealogical classificatory diagram in Čašule (2012: 124).

The Greek-Phrygian correspondences are mainly borrowings from Greek into Phrygian as a result of language contact. The idea of a Phrygian-Greek branch is not supported by respectable evidence. Scholars advocating this or a very close genetic correlation between Ancient Greek and Phrygian (like Lubotsky (1988) or Brixhe and Lejeune (1984), and in particular Brixhe (2002) and Blažek (2005), and most recently Obrador-Cursach 
The possible genetic correlation between Ancient Macedonian and Phrygian within Indo-European should be investigated much more thoroughly. ${ }^{9}$

The study of the Ancient Balkan languages, not only of Phrygian, but even more so of Thracian and Illyrian, while of interest and in focus in the 1960s and 1970s, nowadays attracts much less attention by historical linguists and Indo-Europeanists, which is lamentable and should be remediated.

(2020) essentially tend to overlook and reject Phrygian material that does not fit the model of relatedness to Greek and fail to consult and ignore the cited works by Hamp, Diakonoff, Neroznak and even Orel to which their views are diametrically different.

They do not explain satisfactorily or do not even take into account especially glosses like zemelos, zetna, zeuman, itimbos, dumas (Greek thomos) etc. and many Phrygian forms from the inscriptions like skeledria/skeredria, glossed as 'some funerary structure', but not explained etymologically (see Čašule 2004, 2014 and especially Čašule 2021), which they reject as uncertain. They also do not take into consideration the Phrygian onomasticon and unfortunately tend to dismiss or ignore evidence that does not support their theory of Greek origin of Phrygian.

My upcoming book (Čašule 2021, in print) which covers and interprets all extant Phrygian glosses (totaling 50+) shows decisively that we cannot speak of a Graeco-Phrygian branch $(\mathrm{V}$. Blažek is perhaps the strongest proponent of this groupation which has led to a misguided Wiki entry Graeco-Phrygian (?) (https://en.wikipedia.org/wiki/GraecoPhrygian).

Furthermore, the Phrygian onomasticon is also very divergent from the Greek one and this is not due in most instances to input from the Asia Minor onomasticon but is autochthonous, possibly originating from Macedonia.

On the other hand, we find over 30 onomastic correspondences (analyzed in Čašule 2016: 64-65, or Čašule 2004: 85-92, i.e. section 4.3. Burushaski-Phrygian correspondences in onomastics) between Phrygian and Burushaski names (e.g. the most solid one: Phrygian Arogomachos (Catzopoulos 38) : Burushaski Argumaaq (Berger 1998: 486) Phrygian Kuliyas (Orel 1997: 439) : Burushaski Kulio, Kuli (Berger 1998: 501), Phrygian Silenos : Burushaski Silum.

Especially interesting is the correspondence between the Ancient Macedonian / Phrygian name Brygos or Ancient Macedonian Byrginos (Petrova 1996: 185) with Burushaski Birgao, Birgan (Berger 1998: 490), which once again shows the possible relatedness of Phrygian and Ancient Macedonian.

${ }^{9}$ Phrygian linguistic studies are in my view, in a stage of stagnation. There are still Old Phrygian inscriptions which have not been analyzed or explained fully, and there are conflicting and even contradictory analyses which indicates that the extant method of their reconstruction has some serious fallacies. These insurmountable difficulties perhaps stem from the possibility that Phrygian is an ergative language, as the Burushaski material strongly suggests. 


\section{REFERENCES}

Barić, Henrik. 1948. Ilirske jezične studije. Radovi JAZU, V 272. Zagreb: Jugoslavenska akademija znanosti i umjetnosti.

Berger, Hermann. 1998. Die Burushaski Sprache von Hunza und Nager. Teil I. Grammatik. Teil II. Texte. Teil 3. Wörterbuch. Burushaski-Deutsch, Deutsch-Burushaski. Neuindische Studien. 15. Wiesbaden: Harrasowitz Verlag.

Blažek, Václav. 2005. Paleo-Balkanian Languages I: Hellenic Languages. Sborník prací Filozofické fakulty brněnské univerzity. 10. Brno: Masarykova univerzita. pp. 1533.

Brixhe, Claude and M. Lejeune. 1984. Corpus des inscriptions paleo-phrygiennes. Paris: Recherche sur les civilisations.

Brixhe, Claude. 2002. Interactions between Greek and Phrygian under the Roman Empire. In Adams, J. N.; Janse, Mark (eds.). Bilingualism in Ancient Society: Language Contact and the Written Text. Oxford University Press. pp. 246-266.

Čašule, Ilija. 2004. Burushaski-Phrygian lexical correspondences in myth, ritual and burial. Central Asiatic Journal. 48/1: 50-104.

Čašule, Ilija. 2010. Burushaski as an Indo-European "kentum” Language: Reflexes of the Indo-European Gutturals in Burushaski. Munich: Lincom Europa.

Čašule, Ilija. 2012. Correlation of the Burushaski pronominal system with Indo-European and phonological and grammatical evidence for a genetic relationship. Journal of Indo-European Studies. Vol. 40, 1-2: 59-154.

Čašule, Ilija. 2014. Evidence for a Burushaski-Phrygian connection. Acta Orientalia. 75 : 3-31.

Čašule, Ilija. 2016. Evidence for the Indo-European and Balkan Origin of Burushaski. Munich: Lincom Europa (esp. Chapter 2: "Evidence for a Burushaski-Phrygian Connection: Burushaski hargin 'dragon' and Phrygian argwitas 'dragon' and the Indo-European words for silver (pp. 57-69).

Čašule, Ilija. 2017. Burushaski Etymological Dictionary of the Inherited Indo-European Lexicon. Lincom Etymological Studies 6. Munich: Lincom Europa.

Čašule, Ilija. 2018. New Burushaski etymologies and the origin of the ethnonym Burúśo, Burúśaski, Brugaski and Miśáski. Acta Orientalia. Vol. 79: 27-71.

Čašule, Ilija. 2020. The Indo-European origin of the Burushaski verbal prefixation and its verbal morphology. The Journal of Indo-European Studies. Vol. 48. Numbers 3-4, Fall-Winter: 353- 388.

Čašule, Ilija. 2021. Burushaski and Phrygian. (in print). Munich: Lincom Europa.

Diakonoff, Igor M. and Neroznak, Vladimir P. Phrygian. New York: Caravan Books Delmar.

Haas, Otto. 1966. Die Phrygischen Sprachdenkmaler. Sofia: Bulgarian Academy of Sciences.

Hamp, Eric P. 1990. The Pre-Indo-European language of northern (central) Europe. In Markey, T.L. and Greppin, J.A.C. eds. When Worlds Collide: Indo-European and Pre-Indo-Europeans. Ann Arbor: Caroma.

Hamp, Eric P. 2013. The expansion of the Indo-European languages: An Indo-Europeanist's evolving view. Sino-Platonic Papers. Number 239.

Herodotus of Halicarnassus. 1858. Histories. [translated by George Rawlinson].

Hesychius of Alexandria. $5^{\text {th }}$ [?] century CE "Alphabetical Collection of All Words" ( $\Sigma v-$

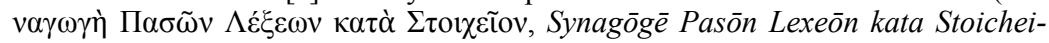
on). 
Hrvatski jezični portal, LOKATI [accessed 22.04.2021] http://hjp.znanje.hr/index.php show $=$ search_by_id\&id=e15iXBY\%3D

Katičić, Radoslav. 1976. Ancient Languages of the Balkans. The Hague: Mouton.

Lorimer, David, L.R. 1938. The Burushaski Language. Vol. 3. Vocabularies and Index. Oslo: Institutet for Sammenlignende Kulturforksning. H. Aschehoug\&Co.

Lubotsky, Alexander. 1988. The Old Phrygian Areyastis inscription. Kadmos. Vol. 27/1: 9-26.

Mallory, James P. and Adams, Douglas Q. (eds.) 1997. Encyclopedia of Indo-European Culture. London-Chicago: Fitzroy Dearborn Publishers.

Neroznak, Vladimir P. 1978. Paleobalkanskie jazyki. Moskva: Nauka.

Obrador-Cursach, Bartomeu. 2020. On the place of Phrygian among the Indo-European languages. Journal of Language Relationship. 17 (3-4).

Orel, Vladimir. 1997. The Language of Phrygians. New York: Caravan Books Delmar.

Petrova, Eleonora. 1996. The Briges in the Central Balkans: 2nd-1st millenium BC [bilingual Macedonian and English edition].

Pokorny, Julius. 1959. Indogermanisches etymologisches Wörterbuch. Bern: Munich.

Walde, Alois and Pokorny, Julius. 1927-1932. Vergleichendes Wörterbuch der Indo-Germanische Sprachen. 3 vols. Berlin: De Gruyter. 
